\title{
Crustal Manifestations of a Hot Transient Pulse Beneath the Mid-Atlantic Ridge near $60^{\circ} \mathrm{N}$
}

\author{
R.E. Parnell-Turner, N.J. White, J. Maclennan \\ Bullard Laboratories, Department of Earth Sciences, University of Cambridge, Cambridge, CB3 OEZ, UK \\ T.J. Henstock, B.J. Murton \\ National Oceanography Centre Southampton, European Way, University of Southampton, SO14 3ZH, UK \\ S.M. Jones \\ School of Geography, Earth and Environmental Sciences, University of Birmingham, Edgbaston, B15 2TT, UK
}

\begin{abstract}
Since its inception at 62 Myrs, mantle convective upwelling beneath Iceland has had a significant influence on the history of vertical motion, magmatism and paleoceanography in the North Atlantic Ocean. Crucially, intersection of the Reykjanes Ridge with the Icelandic plume provides us with an important window into the transient activity of the plume. The spreading ridge acts as a linear sampler of plume activity, which is recorded as a series of time-transgressive V-shaped ridges and troughs. Here, we present the results of a detailed study along the spreading ridge close to $60^{\circ} \mathrm{N}$, where the youngest V-shaped ridge of thickened oceanic crust, is forming today. A combination of multibeam bathymetry and seismic reflection profiles, acquired along and across the ridge axis, is used to map the detailed pattern of volcanism and normal faulting. Along the ridge axis, the density of volcanic seamounts varies markedly, increasing by a factor of two between $59^{\circ}$ and $62^{\circ} \mathrm{N}$. Within this area, seismic imaging shows that there is enhanced acoustic scattering at the seabed. These observations are accompanied by a decrease in mean fault length from $\sim 12 \mathrm{~km}$ to $\sim 6 \mathrm{~km}$. A $1960-$ 2009 catalog of relocated teleseismic earthquake hypocenters shows that there is a pronounced gap in seismicity between $59^{\circ}$ and $62^{\circ} \mathrm{N}$ where the cumulative moment release is two orders of magnitude smaller than that along adjacent ridge segments. A steady-state thermal model is used to show that a combination of increased melt generation and decreased hydrothermal circulation accounts for this suite of observations. Our results suggest that the thickness of the brittle seismogenic layer is smaller where the youngest V-shaped ridge intersects the ridge axis. This decrease is consistent with geochemical modeling of dredged basaltic samples, which require horizontal flow of hotter
\end{abstract}


asthenospheric material within a channel beneath the spreading axis. Thus, along-axis variation in melt supply arising from the passage of a pulse of hot material directly affects crustal accretion processes and rheological properties.

Keywords: Mantle convection; Atlantic Ridge; Iceland; plume; normal faulting; volcanism.

\section{Introduction}

It is widely accepted that convective circulation of the Earth's mantle modifies surface elevation (e.g. Schubert et al., 2001). Such elevation changes are referred to as dynamic topography in order to distinguish it from isostatic topography which is maintained by the changes in the density structure of the lithosphere (Hager et al., 1985; Hager and Richards, 1989; Cazenave et al., 1989). Spatial and temporal variations in dynamic topography play an important role in sculpting terrestrial landscapes and in moderating the overflow of deep water at oceanic gateways (Wright and Miller, 1996; Jones et al., 2001; Poore et al., 2006). In the North Atlantic Ocean, hot plume material rises within a conduit located beneath Iceland and spreads outward beneath the lithospheric plate (Fig. 1 (White, 1997; Delorey et al., 2007). Marine geophysical observations combined with a fluid dynamical understanding of convective upwelling suggest that periodic oscillations within the plume's conduit trigger transient temperature fluctuations which spread out horizontally over large distances (White, 1997; Jones et al., 2002; Schubert and Olson, 1989). These oscillations are manifest in several different ways, including variations in the thickness and chemical composition of oceanic crust, Neogene overflow of North Atlantic Deep Water past the Greenland-Iceland-Scotland Ridge and development of ancient transient landscapes (Jones et al., 2002; Poore et al., 2011; Hartley et al., 2011). Here, we will analyze crustal, bathymetric and earthquake seismological evidence for a hot transient pulse, which is propagating away from Iceland at the present day. Our aim is to develop a quantitative understanding of the way in which this anomaly affects crustal accretion processes and rheology.

The North Atlantic Ocean is a valuable natural laboratory where the behavior of time-dependent convective circulation can be investigated. South of Iceland, the Reykjanes Ridge is a portion of the Mid-Atlantic Ridge system, which is uninterrupted by fracture zones (Fig. 1). The Reykjanes

Email address: rep52@cam.ac.uk (R.E. Parnell-Turner) 
Ridge is flanked by a series of diachronous V-shaped features which were originally described by Vogt (1971). At $60.3^{\circ} \mathrm{N}$, the youngest $\mathrm{V}$-shaped ridge meets the ridge axis where crustal thickness measured in a reversed wide-angle seismic experiment is $10.4 \pm 0.5 \mathrm{~km}$ (Smallwood and White, 1998). At $58.5^{\circ} \mathrm{N}$, the adjacent trough has a projected crustal thickness of $8.6 \pm 0.5 \mathrm{~km}$. Along the ridge axis, systematic variations in major, trace and rare Earth elemental compositions from dredged basaltic rocks correspond to the intersections of V-shaped ridges and troughs (Murton et al., 2002; Jones et al., 2010; Poore et al., 2011). An inverse correlation between crustal thickness and, for example, $\mathrm{Nb} / \mathrm{Y}$ is easily explained by $25-30^{\circ} \mathrm{C}$ fluctuations in $T_{p}$, the asthenospheric potential temperature (Bown and White, 1994; Poore et al., 2011). Thus a range of disparate geophysical, geochemical and paleoceanographic observations support the existence of transient thermal anomalies which are generated within the plume conduit and which flow outward in a horizontal channel (e.g. Vogt, 1971; White, 1997; Ito, 2001; Jones et al., 2002). Nearer to Iceland, detailed magnetic and bathymetric profiles suggest a small asymmetry in the V-shaped ridges for the last 15 Ma (Hey et al., 2010; Benediktsdóttir et al., 2012). This asymmetry can be accounted for by minor changes in the southward propagation of the Reykjanes Ridge. In the last 6 Ma, there is little evidence for asymmetry within the uncertainty of the magnetic anomaly picks, consequently it appears that ridge propagation effects are less important within the last few million years. Furthermore, kinematic models involving ridge propagation (Hey et al., 2010; Benediktsdóttir et al., 2012) do not quantitatively account for the observed variations in crustal thickness and basalt geochemistry associated with the $\mathrm{V}$-shaped ridges, which are central to our understanding processes at the mid-oceanic ridge.

Here, we are interested in the evolution of the region where the youngest V-shaped ridge is now forming at $60^{\circ} \mathrm{N}, \sim 500 \mathrm{~km}$ southwest of Iceland (Fig. 1). A combination of multibeam bathymetric data and two-dimensional seismic reflection profiles acquired over this portion of the Reykjanes Ridge enable us to investigate the structure and evolution of the brittle crust. By combining this analysis with the distribution of teleseismically recorded earthquakes and with the geochemistry of dredged basaltic rocks, we can develop an understanding of how the deeper seated thermal anomaly affects crustal structure. A steady state thermal model of the spreading axis is developed and applied which accounts for a suite of observations.In this way, we examine the influence of magmatic flux at constant spreading rate on crustal accretion processes and test a simple dynamic 
model of faulting and magmatism at mid-ocean ridges (e.g. Chen, 2003; Buck et al., 2005; Behn and Ito, 2008; Ito and Behn, 2008).

\section{Multibeam Bathymetry}

A bathymetric survey was acquired during Cruise JC50 onboard RRS James Cook during JulyAugust 2010. At the Reykjanes Ridge, bathymetric profiles were collected along four flowlines which straddle the ridge centered at $60^{\circ} \mathrm{N}$ and $61.5^{\circ} \mathrm{N}$ (Fig. 1). Additional profiles were collected along the ridge crest itself. These data were acquired using a hull-mounted Kongsberg EM120 multibeam echosounder operating at a frequency of $12 \mathrm{kHz}$ with a swath width which is $\sim 6$ times the average water depth. Processing was carried out using the proprietary Caris HIPS software, yielding a gridded dataset which covers $>28,000 \mathrm{~km}^{2}$. Here, we are concerned with a smaller subset of 1,293 $\mathrm{km}^{2}$ acquired at the ridge crest where the horizontal resolution is $\sim 30 \mathrm{~m}$. This small bathymetric survey overlaps with more extensive surveys collected on Cruise EW9008 (RV Maurice Ewing; Searle et al. (1994)) and on Cruises CD81 and C87 (RRS Charles Darwin; Keeton et al. (1997)). The horizontal resolution of Hydrosweep and EW9008 data from these earlier surveys is $\sim 100 \mathrm{~m}$.

\subsection{Volcanism}

The morphology of the Reykjanes Ridge is dominated by an axial high which is characterized by a series of en echelon axial volcanic ridges (AVRs). These AVRs are covered with circular volcanic seamounts, which often overlap with each other and are sometimes dissected by normal faults (Figure 2). These seamounts have diameters of $\sim 2 \mathrm{~km}$ and heights of 200-300 m. In places, they are dimpled with craters which have depths of more than $100 \mathrm{~m}$. Seamounts are mostly concentrated at the ridge axis and are less apparent at distances greater than $\sim 10 \mathrm{~km}$ away from the axis due to sedimentary burial and faulting. The biggest AVR in the study area has a relief of $\sim 400 \mathrm{~m}$ and a width of $6.5 \mathrm{~km}$ (Figure 2c). Its rugged surface is covered with hummocky and flat-topped seamounts. Detailed interpretations of selected portions of the ridge axis are shown in Figures 2e-g. Using the criteria of Smith and Cann (1992), 205 seamounts were identified within the study region. Of these, $120(59 \%)$ are smooth and 84 (41\%) are hummocky, which is consistent with the study of Magde and Smith (1995) who used side-scan sonar images from a $140 \mathrm{~km}$ segment of ridge axis at $60^{\circ} \mathrm{N}$. However, there is a marked difference in the abundance of seamounts and in seabed morphology along the ridge axis. In the south (e.g. Figures $2 \mathrm{~b}-\mathrm{c}$ ), there is a higher 
density of seamounts. Many of the seamounts have craters and the seabed is characterized by short wavelength hummocky features. In the north (e.g. Figure 2d), the density of seamounts is considerably reduced and the seabed is much smoother. These results are consistent with the bathymetric study of Appelgate and Shor (1994) who analyzed seamount density between $56^{\circ}$ and $63^{\circ} \mathrm{N}$ (Figure $7 \mathrm{c}$ ). Their maximum seamount density is centered on $60^{\circ} \mathrm{N}$.

\subsection{Tectonic Structure}

Normal faults occur along the length of the ridge axis but their distribution and size changes markedly as a function of distance (Figures 2 and $3 \mathrm{~b}$ ). To ensure self-consistency, we have reinterpreted fault scarps between $\sim 57^{\circ}$ and $63^{\circ} \mathrm{N}$ using the lower resolution bathymetric survey from Cruise CD87 (Keeton et al. (1997); Figure 3b). The largest number of faults occur south of $59.5^{\circ} \mathrm{N}$. Here, fault scarps have displacements of $>200 \mathrm{~m}$ and fault lengths range from 2-30 km with a mean value of $12 \mathrm{~km}$. Fault density (i.e. cumulative fault length) is $120 \mathrm{~m} \mathrm{~km}^{-2}$. North of $59.5^{\circ} \mathrm{N}$ and south of $61.5^{\circ} \mathrm{N}$, the mean fault length halves to $\sim 6 \mathrm{~km}$, fault density drops to $40 \mathrm{~m}$ per $\mathrm{km}^{2}$, and fault displacement is less than $200 \mathrm{~m}$. North of $61.5^{\circ} \mathrm{N}$, mean fault length increases to $7 \mathrm{~km}$ and fault density doubles to $80 \mathrm{~m}$ per $\mathrm{km}^{2}$.

These results are borne out by the higher resolution bathymetric images shown in Figure 2 . North of $61.5^{\circ} \mathrm{N}$, long sinuous normal faults with lengths of up to $12 \mathrm{~km}$ are visible (Figure $2 \mathrm{~d}$ ). Further south, the average fault length is much smaller $(\sim 6 \mathrm{~km})$. In both cases, fault displacements are $\sim 100 \mathrm{~m}$. The dramatic change in the distribution and geometry of faulting between $59.5^{\circ} \mathrm{N}$ and $61.5^{\circ} \mathrm{N}$ coincides with the intersection between the youngest $\mathrm{V}$-shaped ridge with the spreading axis. This coincidence suggests that the thermo-mechanical properties of the upper crust have been altered by the presence of a transient thermal anomaly traveling beneath the spreading axis.

\section{Seismic Reflection Imaging}

A set of regional seismic reflection profiles was also acquired as part of Cruise JC50 in JulyAugust 2010. The centerpiece of this survey is a pair of flowlines, which traverse the oceanic basin from the European Shelf to the Greenland Shelf and enable us to elucidate the history of V-shaped ridge activity for the last $50 \mathrm{Ma}$. The small fraction of this survey exploited here was acquired along and adjacent to the mid-oceanic ridge between $60^{\circ}$ and $62^{\circ} \mathrm{N}$ (Figure 2a). The seismic reflection experiment was acquired using a single generator-injector (GI) airgun (primary pulse = 
250 inch $^{3}$, injector pulse $=105$ inch $^{3}$ ) fired at a pressure of 3,000 pounds inch ${ }^{-2}$ every 15 seconds. The nominal ship speed was 5 knots $(\sim 9.3 \mathrm{~km} / \mathrm{hr})$ which gives a shot spacing of $\sim 40 \mathrm{~m}$ and a fold of $\sim 21$. A standard signal processing sequence was applied. After sorting into common mid-point gathers, a low-cut Butterworth filter with a cut-off frequency of $12 \mathrm{~Hz}$ and a slope of $24 \mathrm{~dB} /$ octave was applied to remove incoherent noise. Stacking velocities were picked every 625 $\mathrm{m}$ using a combination of semblance analyses and constant velocity stacking panels. Post-stack extended frequency-wave Stolt migration was then applied, using a constant (water) velocity of $1500 \mathrm{~m} / \mathrm{s}$.

By combining the seismic profiles with the multibeam bathymetric dataset of Keeton et al. (1997), we can image the three-dimensional geometry of the AVRs and their constituent volcanic edifices (Figs. 5 and 6). Three AVRs are clearly seen in cross-section at the southern end of the study area, together with a pair of cratered seamounts (Fig. 5b). Uneven topography at the Reykjanes Ridge is probably the cause of high amplitude noise which contaminates the seismic data at $0.2-0.6 \mathrm{~s}$ two-way time (TWT) below the seabed in Fig. 5a. These steeply dipping, noisy arrivals are a consequence of scattering from uneven seabed topography in- and out-of-the-plane of the profile (Calvert, 1997; Peirce et al., 2007). This scattering conceals lower amplitude mid-crustal reflections. The region near $60^{\circ} \mathrm{N}$ shown in Fig. 5 shows more steeply dipping scattered arrivals between $0.2-0.6 \mathrm{~s}$ below the seabed when compared to more northerly section shown in Fig. 6 . The increase in scattered arrivals is likely due to a chaotic seabed in the region of $60^{\circ} \mathrm{N}$, caused by recent intensified volcanism generating an irregular landscape of volcanic edifices and seamounts. We do not see evidence for magma chambers beneath the ridge. However, given the large amount of scattered noise within the dataset, any intra-crustal events are likely to have been obscured.

The uppermost crust, known as layer 2, consists mainly of extrusive basalts and sheeted dykes, and is conventionally divided into two layers, $2 \mathrm{~A}$ and $2 \mathrm{~B}$. The origin of the basal layer $2 \mathrm{~A}$ reflection remains a matter of debate and it could represent the geologic boundary between lavas and dykes (e.g. Harding et al., 1993; Canales et al., 2005), or alternatively it may relate to an alteration boundary within the upper crust due to hydrothermal circulation and sealing of cracks (e.g. Vera et al., 1990; Christeson et al., 2007). At $61^{\circ} 40^{\prime} \mathrm{N}$ on the Reykjanes Ridge, seismic refraction experiments show that layer $2 \mathrm{~A}$ is $\sim 400 \pm 130 \mathrm{~m}$ thick, characterized by a velocity increase from $2.4 \mathrm{~km} \mathrm{~s}^{-1}$ to $4.8 \mathrm{~km} \mathrm{~s}^{-1}$ at its base (Smallwood and White, 1998). No consistent layer $2 \mathrm{~A}$ 
reflector is apparent on Figs. 5 and 6, which is unsurprising given the relatively short maximum offset used for this study, and is similar to the seismic reflection results described elsewhere on the mid-Atlantic ridge and East Pacific Rise (e.g. Christeson et al., 1996; Smallwood and White, 1998). Examination of shot gathers and far-offset stacks does not reveal any further improvement in our ability to detect layer $2 \mathrm{~A}$ reflectors. Despite these restrictions, we suggest the observed increase in amplitude and abundance of low-level scatterers near $60^{\circ} \mathrm{N}$ is due to uneven seabed morphology in that area. We suggest the increased scattering behavior is related to the increase in extrusive lavas near $60^{\circ} \mathrm{N}$, which is in agreement with our observation of increased seamount frequency in that region.

\section{Earthquake Seismicity}

The distribution and character of earthquakes at mid-ocean ridges provide helpful information about the thermal and mechanical properties of developing oceanic lithosphere. For example, the depth of faulting determines the depth of the brittle-ductile transition in the axial region, which in turn helps to constrain thermal and mechanical models of spreading centers (Toomey et al., 1985; Huang and Solomon, 1988). Local seismicity also provides an insight into the balance between tectonic and magmatic related extensional processes.

We use relocated teleseismic earthquake hypocenters covering a timespan of almost 50 years from 1960 to 2009 (Engdahl et al., 1998). Fig. 1 shows the regional distribution of earthquakes in the North Atlantic Ocean, which closely defines the location of the mid-oceanic ridge. There is a notable gap in seismicity approximately $540 \mathrm{~km}$ south west from Iceland, which corresponds to the region of interest described above where the youngest V-shaped ridge is forming. We select earthquakes located within $35 \mathrm{~km}$ of the spreading axis with magnitudes greater than 4.0, although note the database is likely to only be complete for magnitudes higher than 5.2. Uncertainty in epicenter location is about one order of magnitude less than the $100 \mathrm{~km}$ wavelength of the local anomaly we are concerned with identifying here, and therefore is not significant for the following discussion.

Earthquakes at the Reykjanes Ridge are typically shallow $(<10 \mathrm{~km})$, making depth estimates highly uncertain. Consequently, we do not consider epicentral depths in our analysis. Fig. 3b shows the seismicity in the area surrounding the youngest $\mathrm{V}$-shaped ridge. There is a zone of 


\subsection{Seismic moment release}

Using the seismic moment for individual earthquakes, we can estimate the change in rupture radius along the Reykjanes Ridge . Following Eshelby (1957), who assumed that faults behave as 
circular cracks,

$$
M_{\circ}=\frac{16}{7} \Delta \sigma a^{3}
$$

where $a$ is the rupture radius and $\Delta \sigma$ is the stress drop, which is assumed to be constant along the ridge axis. Along-axis variation in rupture radius is shown in Fig. 4b. A $M_{w} 4.5$ earthquake (common amongst those near $60^{\circ} \mathrm{N}$ ) has a rupture radius of $\sim 1 \mathrm{~km}$ with a $\Delta \sigma$ of $3 \mathrm{MPa}$ (Hanks, 1977). For the same stress drop, rupture radius is more than doubled to $\sim 2.2 \mathrm{~km}$ for a $M_{w} 5.2$ earthquake, typical for the Reykjanes Ridge to the north and south of where the youngest V-shaped ridge is forming. This shows good agreement with the pattern of reduced fault lengths observed with the multibeam bathymetry shown in Fig. 4a.

\section{Basalt geochemistry}

Murton et al. (2002) present a study of basalts dredged from the present-day Reykjanes Ridge. Their data includes an array of major, minor and trace element compositions as well as isotope data from closely-spaced samples along the ridge between $57.3^{\circ} \mathrm{N}$ and $63^{\circ} \mathrm{N}$. The data spans the intersection of a trough-ridge-trough set of V-shaped gravity and bathymetry features with the Reykjanes Ridge, corresponding to the present positions of mantle pulses. Major element data display a coherent trend; incompatible elements show a general decrease northwards from $57.5^{\circ} \mathrm{N}$ to a minimum at $60.75^{\circ} \mathrm{N}$. Incompatible trace elements and their ratios show a similar pattern, with a small peak at latitudes corresponding to $58.5^{\circ} \mathrm{N}$ and a minimum at the location of the currently forming V-shaped ridge. Values of all the trace element ratios increase rapidly at latitudes greater than $\sim 61^{\circ} \mathrm{N}$, as the Iceland plume is approached. Poore et al. (2011) use the trace element ratio, $\mathrm{Nb} / \mathrm{Y}$, to show this variation because it is relatively insensitive to crustal processes (e.g. fractional crystallization). Instead, $\mathrm{Nb} / \mathrm{Y}$ reflects mantle melt composition which is controlled by a combination of source composition, depth of melting, and degree of melting.

A northward increase of $\mathrm{Nb} / \mathrm{Y}$ between $61^{\circ} \mathrm{N}$ and $63^{\circ} \mathrm{N}$ (see Fig. 7e) correlates with shallowing of the Reykjanes Ridge, with a gradual increase in crustal thickness, and with increasing source enrichment estimated by isotopic variation. Geochemical enrichment closer to Iceland results from melting of compositional heterogeneities within the plume conduit (Shorttle and Maclennan, 2011). Melting during southward flow along the ridge axis progressively removes out these heterogeneities (Murton et al., 2002). Poore et al. (2011) suggested that spatial changes in trace element chemistry 
and crustal thickness along the Reykjanes Ridge close to Iceland are primarily caused by changes in the temperature of asthenospheric mantle directly beneath the ridge. The size of this temperature change is of the order of $25^{\circ} \mathrm{C}$ from $\mathrm{V}$-shaped ridge to $\mathrm{V}$-shaped trough, which is compatible with the results of Smallwood and White (1998), who report crustal thickness changes from 8.6 to $10 \mathrm{~km}$ at locations shown in Fig. 7e. Mantle compositional variation alone is unlikely to generate both the changes in chemistry (rare earth element patterns, concentrations and trace element ratios) and the required crustal thickness variations.

\subsection{Crustal magnetization}

We summarize along-axis variations in crustal magnetization calculated by Lee and Searle (2000), who exploited magnetic data acquired during Cruise CD87. Their 3D inversion scheme assumes a $500 \mathrm{~m}$ thick magnetic source layer. The axial zone is characterized by a consistent magnetization high, a common feature of oceanic spreading centers, known as the central anomaly magnetic high $(\mathrm{CAMH})$. The $\mathrm{CAMH}$ reflects the presence of recently emplaced and highly magnetic lavas, attributed to strongly magnetized titanomagnetite in young pillow basalts, erupted over the past 800 kyrs while the geomagnetic paleointensity has been highly positive (Marshall and Cox, 1972; Klitgord, 1976). Lee and Searle (2000) report changes in the magnitude and regularity of magnetization along the ridge axis, shown in Fig. 7a. Ignoring local features, the axial region south of $59.2^{\circ} \mathrm{N}$ shows the highest magnetization anomaly, and the highest degree of irregularity, punctuated by a few isolated magnetization lows. Axial magnetization is at its lowest between $59.2^{\circ} \mathrm{N}$ and $60.8^{\circ} \mathrm{N}$, although there are local exceptions to this trend. North of $60.8^{\circ} \mathrm{N}$, axial magnetization increases, returning to the elevated values normally associated with the CAMH. The zone of low magnetization intensity shows a broad correlation to the variations in faulting style and basalt geochemistry described earlier, and will be discussed further below.

\section{Thermal Modeling}

A thermal model can be used to explain the observations of faulting, seismicity and volcanism described above. The basis for this model is our knowledge of variations in crustal thickness and basalt geochemistry, which can be explained by the asthenosphere beneath the Reykjanes Ridge at $60^{\circ} \mathrm{N}$ having $T_{p}$ about $25^{\circ} \mathrm{C}$ hotter the regions $\sim 150 \mathrm{~km}$ to the north and south. The nature of faulting at slow-spreading ridges is highly sensitive to the thermal structure at the ridge axis, 
and therefore provide us with clues as to how the Reykjanes Ridge varies along-axis. Here, our objective is to reconcile the observed changes in faulting shown in Fig. 4 with the observed changes in crustal thickness and $T_{p}$. Our model includes latent heat released at the axis. Hydrothermal circulation is modeled as a series of discrete heat sinks at or near the axis, following the method of Morton and Sleep (1985). Our approach is concerned with steady-state temperature distribution in the the neovolcanic zone, which we define as having a width of $35 \mathrm{~km}$ either side of the ridge axis. We have kept this model deliberately as simple as possible and have tried to only include features required to match the observations.

The temperature field, $T(x, z)$, must satisfy the advection-diffusion equation

$$
u \frac{\partial T}{\partial x}=\kappa\left(\frac{\partial^{2} T}{\partial x^{2}}+\frac{\partial^{2} T}{\partial z^{2}}\right)+Q(x, z)
$$

where $u$ is half-spreading rate, $T$ is temperature, $x$ is distance from ridge, $z$ is depth, $\kappa$ is thermal diffusivity, and $Q$ represents heat sources and sinks due to due to latent heat and hydrothermal circulation (Sleep, 1974, 1975; Morton and Sleep, 1985). The solution can be tackled in two steps. First, we consider heat brought in by intrusion at the axis; latent heat is explicitly included in the adiabatic melting of ascending material and subsequent solidification of basaltic crust. Equation (2) is solved following the approach of Sleep (1975). Secondly, we solve for the temperature field generated by off-axis heat sinks, in a similar manner to Morton and Sleep (1985). The results are then combined to yield the complete temperature distribution. Values of constants used are in Table 1. Details of the approach we use can be found in Appendix A and Appendix B. Finally, the temperature field is incorporated into a simple two layer rheological model, which we use to calculate the depth of the brittle-ductile transition. At low temperatures, brittle strength is controlled by a frictional resistance law (Byerlee, 1978). The criterion for failure of normal faults can be written as

$$
\sigma_{1}-\sigma_{3}=\frac{R^{\prime}-1}{R^{\prime}} \rho g z(1-\lambda)
$$

where $\sigma_{1}$ and $\sigma_{3}$ are the maximum and minimum principle stresses, $R^{\prime}$ is the ratio $\sigma_{1} / \sigma_{3}=5$ (Brace and Kohlstedt, 1980), and $\lambda$ is the pore fluid factor $=0.4$ (Sibson, 1974; Ranalli, 1995). At higher temperatures, plastic deformation occurs according to the temperature-dependent steady- 
state creep law (Goetze and Evans, 1979; Kirby, 1983) so that

$$
\dot{\varepsilon}=A\left(\sigma_{1}-\sigma_{3}\right)^{n} \exp \frac{-Q}{R T}
$$

where $\dot{\varepsilon}$ is uniaxial strain rate, $A$ is a material strength constant, $n$ is the power-law exponent, $Q$ is the activation energy for creep, $R$ is the gas constant and $T$ is temperature in Kelvin. Values of constants used can be found in Supplementary Table 1.

Following Sleep (1975) and Morton and Sleep (1985), we consider material rising from the asthenosphere at the ridge, with a temperature of $T_{l}$. We assume initially that ascending material follows a dry adiabat, $\theta$, until reaching a depth of $80 \mathrm{~km}$, where melting commences, $z_{s}$. A melting gradient, $\beta$, is then followed until reaching the base of the crust $\left(t_{c}\right)$, at which point a liquid adiabat, $\alpha$, is used to represent crystallization within the crust. Latent heat is assumed to be released uniformly within the crust as material cools adiabatically.

The distribution of hydrothermal circulation has a dramatic effect on the calculated temperature field. Maximum fluid temperatures observed at mid-Atlantic Ridge seafloor vents are $\sim 324^{\circ} \mathrm{C}$ (e.g. Charlou et al., 2000), giving a minimum estimate of the temperature of crust that seawater passes through. The episodic nature of high-temperature circulation (Baker and Massoth, 1987; Baker et al., 1989) means that heat exchange does not occur between rising fluids and surrounding crust, since convective cells are not stable over long time periods. This constraint permits the use of heat sinks to represent hydrothermal circulation in the model. At the slow spreading ridges, hydrothermal fluids may penetrate deep into the crust. Calcium-in-olivine geospeedometry of gabbros drilled at the Southwest Indian Ridge suggest no decrease in cooling rate with depth (Coogan et al., 2007). Similar evidence from Oman suggests that the entire thickness of crust may be cooled by hydrothermal circulation (VanTongeren et al., 2008). Consequently, we permit heat sinks to extend to the base of the crust. Placing all the latent heat at the axis, and initially ignoring hydrothermal heat sinks, we calculate the temperature field at the ridge. Heat sinks are then added within a $1 \mathrm{~km}$ wide corridor extending to the base of the crust. The total (i.e. vertically integrated) heat removed is distributed such that the magnitude of sinks exponentially decreases away from the edge of the axis in a manner similar to that described by Henstock et al. (1993) and by Maclennan et al. (2004). Combining these results yields a temperature distribution, which is used to calculate a strength envelope. Mechanical rock properties are for that of dolerite (Table 
1).

\subsection{Model results}

In order to investigate the effects of along-axis variations in heat input and removal we calculate models for a range of crustal thicknesses, reflecting varying $T_{p}$ and consequent variation in magma flux for a given spreading rate, and total hydrothermal cooling. Results of models representing a $\mathrm{V}$-shaped ridge and a $\mathrm{V}$-shaped trough (with crustal thickness of $10 \mathrm{~km}$ and $8 \mathrm{~km}$, respectively) are shown in Fig. 8. Comparing Fig. 8b with Fig. 8d, we find a twofold increase in the depth to brittle-ductile transition when crustal thickness is decreased from $10 \mathrm{~km}$ to $8 \mathrm{~km}$ under constant hydrothermal cooling conditions of $100 \mathrm{kWm}^{-1}$. The rheological behavior of a material is principally controlled by the homologous temperature, $\tau$, which is the ratio of the temperature of a material to that of its melting point, both measured in Kelvin (Ashby and Verrall, 1977; Weertman, 1978). Materials can only maintain stresses over geologic time if $\tau$ is less than about 0.4. Assuming a gabbroic composition with solidus of $\sim 900^{\circ} \mathrm{C}$ (Coogan et al., 2001), then $\tau=0.4$ corresponds to a temperature of $196^{\circ} \mathrm{C}$. There is good agreement between depth to $196^{\circ} \mathrm{C}$ isotherm and the depth to brittle-ductile transition (Fig. 8).

Additional modeling runs, where total hydrothermal cooling is varied from 50 to $100 \mathrm{kWm}^{-1}$, are summarized in Fig. 8e. Details of the distribution of hydrothermal heat sinks and resulting temperature distribution for all of the models are shown in Supplementary Fig. 1. For each of the different total hydrothermal cooling cases, there remains a significant decrease in depth to brittleductile transition when crustal thickness is increased from $8 \mathrm{~km}$ to $10 \mathrm{~km}$, reflecting measured magmatic heat input. A shallowing of the brittle-ductile transition implies that brittle deformation will be diminished, and as a result, faulting may play a less important role in accommodating strain where the crust is relatively hot and thick. This conclusion is in good agreement with our earlier independent observations of decreased fault length and a factor of two decrease in rupture radii at $60^{\circ} \mathrm{N}$, where the crust is $10 \mathrm{~km}$ thick and $T_{p}$ is $25^{\circ} \mathrm{C}$ hotter than to the north and south.

\section{Discussion}

The observations described above provide us with an opportunity to investigate the bathymetric and crustal rheological consequences of the plume pulsing model for an actively forming V-shaped ridge. Systematic changes in the shallow crust and upper mantle, which coincide at the location 
where the youngest $\mathrm{V}$-shaped ridge is forming at $60^{\circ} \mathrm{N}$ on the Reykjanes Ridge, are summarized in Fig 7. The higher abundance of seamounts observed at $60.5^{\circ} \mathrm{N}$ (Fig. 7c) suggests increased supply of melt to the surface in this part of the Reykjanes Ridge . Alternatively, magma sources in this region could be more episodic or thinly distributed, resulting in more points of eruption. The lack of evidence for a magma chamber in the seismic data supports this notion that any magma sources may be discontinuous. Since the seamount density reduces again to the north, it is not possible to explain the increase in magmatic activity simply due to increased proximity to the Iceland plume. The dominance of smooth-textured seamounts is also a distinguishing feature of this area. Hummocky seamounts form when eruption rates are low and cooling of the surface is rapid, resulting in features that build bulbous outgrowths. In contrast, smooth seamounts form when eruptions rates are higher and cooling is slower; in this case, features are built from flows which spread outward generating little surface texture (Smith et al., 1995). Although surface morphology of seamounts is likely to be controlled by the complex interplay of several variables including magma viscosity and density, eruption rate and surface cooling rate, long-wavelength variations are primarily driven by eruption rate (Magde and Smith, 1995; Cann and Smith, 2005). The increased acoustic scattering between $59.5^{\circ} \mathrm{N}$ and $61.5^{\circ} \mathrm{N}$ compared to region north of $61.5^{\circ} \mathrm{N}$ can be explained due to a more heterogeneous lavas at the seabed, which are present as a result of increased volcanism.

Observed patterns in along-axis magnetization coincide with the bathymetric indicators of increased magmatism; there is a good correlation between the increase in seamount density, decrease in faulting and reduction in magnetization intensity. Variations in the thickness of the magnetic layer may explain the observed patterns in magnetization intensity. The model of Lee and Searle (2000) used here considers a constant thickness of $500 \mathrm{~m}$, which does not account for the changing frequency of seamounts and magma supply in the shallow crust. Minor changes in geomagnetic intensity have been shown to be sufficient to account for magnetization contrasts at the CAMH (Gee et al., 2000), while the role of rapid alteration processes is thought to be less important (Kent and Gee, 1996; Zhou et al., 2000). The paleointensity record for the past 80 kyrs of Gee et al. (2000) can be used to explain the pattern of magnetization associated with the most recent volcanism at the ridge. Paleointensities for the past 1-3 kyrs are significantly higher than the present field value, whereas very low values are associated with the Laschamp excursion which occurred 
at $46.6 \pm 2.4 \mathrm{kyr}$ (Levi et al., 1990). Values between 80 and 46.6 kyrs are again higher. The low magnetization intensity values seen between $59.2^{\circ} \mathrm{N}$ and $60.8^{\circ} \mathrm{N}$ may be associated with the Laschamp excursion, suggesting volcanism here occurred within the last 46.6 kyrs. Submersible dives over AVRs associated with magnetization intensity highs in the region of $59.5^{\circ} \mathrm{N}$ found no evidence for recent submarine volcanism (Crane et al., 1997), suggesting this and other local magnetization highs along the ridge may be associated with older periods of volcanic activity, prior to the Lashchamp excursion.

The reduction in faulting observed on the multibeam bathymetry in the region of $60^{\circ} \mathrm{N}$ corresponds to where earthquake activity is absent. The reduction in rupture radius and brittle layer thickness calculated from the seismic moment release both suggest that brittle deformation is inhibited in the region where the youngest V-shaped ridge is forming. We can reconcile all of these observations with the results of our thermal models, which are consistent with a transient mantle thermal anomaly. The models demonstrate that enhanced heat supply, associated with a temperature increase of $25^{\circ} \mathrm{C}$ at the base of the lithosphere, is sufficient to cause a twofold decrease in depth to the brittle-ductile transition. This effect may be modified by changes in the amount of hydrothermal cooling. The presence of increased melt in the crust may inhibit the propagation of faults, by accommodating deformation by magmatic extension. This mechanism has built-in positive feedback: if faulting is reduced, hydrothermal fluid penetration is reduced and heat removal is further inhibited, thereby causing further suppression of brittle deformation.

Comparing our local results from the Reykjanes Ridge to the wider mid-Atlantic Ridge and Kolbeinsey Ridge systems, we can investigate whether similar patterns in seismicity occur elsewhere. Fig. 1 shows the distribution of seismicity across the North Atlantic and Norwegian Seas, which clearly defines the loci of spreading centers. The gap in seismicity between $59.5^{\circ}$ and $61.5^{\circ} \mathrm{N}$ on the Reykjanes Ridge is not repeated to the south, where seismicity continues unbroken until reaching the Bight Fracture Zone. North of $61.5^{\circ} \mathrm{N}$, events occur along the Reykjanes Ridge up to Iceland where seismicity is subdued, perhaps due to the increased heat supply. North of Iceland, along the Kolbeinsey Ridge, there is less seismic activity, and a complete lack of events with $\mathrm{M}_{W}>4$ along a $140 \mathrm{~km}$-long section of ridge between $69^{\circ}$ and $70^{\circ} \mathrm{N}$. This aseismic ridge section lies approximately $650 \mathrm{~km}$ away from the present day Iceland plume center of Shorttle et al. (2010), which is a similar distance away as the aseismic section of the Reykjanes Ridge discussed earlier. Evidence 
for V-shaped ridges between the Kolbeinsey Ridge and the Jan Mayen continental fragment can be seen in the gravity field (Fig. 1b); however, these features are not as clear as the Reykjanes V-shaped ridges due to damping of the gravity signal by $4 \mathrm{~km}$ of overlying sediments shed from Greenland (Jones et al., 2002). Nonetheless, we note the coincidence of two conjugate sets of Vshaped features, and aseismic ridge sections occurring at similar distances from the Iceland plume center. This symmetry along the ridge axis about the plume center gives strength to the pulsing plume model, and is suggestive of a planform plume head geometry.

\section{Conclusions}

Geophysical data acquired at the Reykjanes Ridge between $60^{\circ}$ and $62^{\circ} \mathrm{N}$ have been presented. We have described variations in the shallow crust in terms of volcanic terrain, faulting styles and seabed character. Seamount distribution and crustal magnetization data have allowed us to investigate the wider Reykjanes Ridge from $57^{\circ}$ to $63^{\circ} \mathrm{N}$. The deeper crust and mantle structure have been characterized in terms of earthquake distribution and basalt geochemistry. The region between $59.5^{\circ}$ and $61.5^{\circ} \mathrm{N}$, where the youngest V-shaped ridge intersects the Reykjanes Ridge , shows a local increase in seamount density, more chaotic seabed texture, reduced faulting and subdued magnetization intensity. These observations coincide with reduced seismicity and with a local minimum in incompatible trace element concentrations in basalt samples.

There is evidence for increased magmatism on the Reykjanes Ridge between $59.5^{\circ}$ and $61.5^{\circ} \mathrm{N}$. Reduced faulting and a near absence of seismicity between $59.5^{\circ}$ and $61.5^{\circ} \mathrm{N}$ suggest that tectonic processes play a secondary role in accommodating plate spreading where the youngest $\mathrm{V}$-shaped ridge is forming. There is geochemical evidence for slightly hotter mantle material presently located beneath the Reykjanes Ridge between $59.5^{\circ}$ and $61.5^{\circ} \mathrm{N}$. We suggest that localized heating effects of a thermal pulse are responsible for the changes in shallow and deep crustal properties described in this study. Thermal model results show that a lithospheric temperature perturbation of $25^{\circ} \mathrm{C}$, associated with crustal thickness increase of $2 \mathrm{~km}$, is sufficient to produce a twofold decrease in depth to the brittle-ductile transition. We suggest the along-axis decrease in faulting and seismicity can be explained by a modification of the brittle deformation regime by such a thermal perturbation. This is in good agreement with a factor of two decrease in the rupture radius estimated from teleseismic earthquake data in the region of $60^{\circ} \mathrm{N}$. 
The pulsing plume model for the formation of the V-shaped ridges south of Iceland provides a framework in which a set of disparate observations can be placed. Further investigation into the symmetrical nature of the seismicity and V-shaped features north and south of Iceland may allow us to understand the geometry of pulses in the future.

\section{Acknowledgments}

The enthusiastic co-operation of the Master, crew and scientists aboard RRS James Cook cruise JC50 is gratefully acknowledged. We are grateful to R. Searle who provided multibeam bathymetric data and the magnetization intensity map from cruise CD87. We thank A. Copley, K. Czarnota, M. Parsons, G. Roberts and J. Rudge for valuable discussions. D Bohnensteihl and an anonymous reviewer provided constructive comments which greatly improved the manuscript. This work is partly supported by Natural Environment Research Council Grant NE/G007632/1. RPT is supported by the University of Cambridge Girdler Fund. Cambridge Earth Sciences Contribution Number XXXX.

\section{References}

Appelgate, B., Shor, A.N., 1994. The northern Mid-Atlantic and Reykjanes Ridges: Spreading center morphology between $55^{\circ} 50^{\prime} \mathrm{N}$ and $63^{\circ} 00^{\prime} \mathrm{N}$. J. Geophys. Res. 99, 17935-17956.

Ashby, M.F., Verrall, R.A., 1977. Micromechanisms of Flow and Fracture, and their Relevance to the Rheology of the Upper Mantle. Philos. Trans. R. Soc. Lond. A 288, 59-95.

Baker, E.T., Lavelle, J.W., Feely, R.A., Massoth, G.J., Walker, S., 1989. Episodic Venting of Hydrothermal Fluids From the Juan de Fuca Ridge. J. Geophys. Res. 94, 9237-9250.

Baker, E.T., Massoth, G.J., 1987. Characteristics of hydrothermal plumes from two vent fields on the Juan de Fuca Ridge, northeast Pacific Ocean. Earth Planet. Sci. Lett. 85, 59-73.

Behn, M.D., Ito, G., 2008. Magmatic and tectonic extension at mid-ocean ridges: 1. Controls on fault characteristics. Geochem. Geophys. Geosyst 9, doi:10.1029/2008GC001965.

Benediktsdóttir, A., Hey, R., Martinez, F., Hoskuldsson, A., 2012. Detailed tectonic evolution of the Reykjanes Ridge during the past 15 Ma. Geochem. Geophys. Geosyst 13, doi:10.1029/2011GC003948.

Bown, J., White, R.S., 1994. Variation with spreading rate of oceanic crustal thickness and geochemistry. Earth Planet. Sci. Lett. 121, 435-449.

Brace, W.F., Kohlstedt, D.L., 1980. Limits on lithospheric stress imposed by laboratory experiments. J. Geophys. Res. 85, 6248-6252.

Buck, W.R., Lavier, L.L., Poliakov, A.N.B., 2005. Modes of faulting at mid-ocean ridges. Nature 434, 719-723. 
Byerlee, J., 1978. Friction of rocks. Pure and Applied Geophysics 116, 615-626.

Calvert, A.J., 1997. Backscattered coherent noise and seismic reflection imaging of the oceanic crust: An example from the rift valley of the Mid-Atlantic Ridge at $23^{\circ}$ N. J. Geophys. Res. 102, 5119-5133.

Canales, J.P., Detrick, R.S., Carbotte, S.M., Kent, G.M., Diebold, J.B., Harding, A., Babcock, J., Nedimovic, M.R., 2005. Upper crustal structure and axial topography at intermediate spreading ridges: Seismic constraints from the southern Juan de Fuca Ridge. J. Geophys. Res. 110, doi:10.1029/2005JB003630.

Cann, J., Smith, D., 2005. Evolution of volcanism and faulting in a segment of the Mid-Atlantic Ridge at $25^{\circ}$ N. Geochem. Geophys. Geosyst 6, doi:10.1029/2005GC000954.

Cazenave, A., Souriau, A., Dominh, K., 1989. Global coupling of Earth surface topography with hotspots, geoid and mantle heterogeneities. Nature 340, 54-58.

Charlou, J.L., Donval, J.P., Douville, E., Jean-Baptiste, P., Radford-Knoery, J., Fouquet, Y., Dapoigny, A., Stievenard, M., 2000. Compared geochemical signatures and the evolution of Menez Gwen (37 50 ’N) and Lucky Strike $\left(37^{\circ} 17^{\prime} \mathrm{N}\right)$ hydrothermal fluids, south of the Azores Triple Junction on the Mid-Atlantic Ridge. Chemical Geology $171,49-75$.

Chen, Y.J., 2003. Influence of the Iceland mantle plume on crustal accretion at the inflated Reykjanes Ridge: Magma lens and low hydrothermal activity? J. Geophys. Res. 108, doi:10.1029/2001JB000816.

Christeson, G.L., Kent, G.M., Purdy, G.M., Detrick, R.S., 1996. Extrusive thickness variability at the East Pacific Rise, $9^{\circ}-10^{\circ} \mathrm{N}$ : Constraints from seismic techniques. J. Geophys. Res 101, 2859-2873.

Christeson, G.L., McIntosh, K.D., Karson, J.A., 2007. Inconsistent correlation of seismic layer 2a and lava layer thickness in oceanic crust. Nature 445, 418-421.

Coogan, L., Wilson, R.N., Gillis, K.M., MacLeod, C.J., 2001. Near-solidus evolution of oceanic gabbros : Insights from amphibole geochemistry. Geochimica et Cosmochimica Acta 65, 4339 - 4357.

Coogan, L.A., Jenkin, G.R.T., Wilson, R.N., 2007. Contrasting Cooling Rates in the Lower Oceanic Crust at Fastand Slow-spreading Ridges Revealed by Geospeedometry. J. Petrol. 48, 2211-2231.

Crane, K., Johnson, L., Appelgate, B., Nishimura, C., Böning, C., Jones, C., Vogt, P.R., Yan, R.K.O.S., 1997. Volcanic and Seismic Swarm Events on the Reykjanes Ridge and Their Similarities to Events on Iceland: Results of a Rapid Response Mission. Mar. Geophys. Res. 19, 319-338.

Davis, E.E., Lister, C.R.B., 1974. Fundamentals of ridge crest topography. Earth Planet. Sci. Lett. 21 , $405-413$.

Delorey, A., Dunn, R.A., Gaherty, J.B., 2007. Surface wave tomography of the upper mantle beneath the Reykjanes Ridge with implications for ridge hot spot interaction. J. Geophys. Res. 112, doi:10.1029/2006JB004785.

Einarsson, P.A., 1979. Seismicity and earthquake focal mechanisms along the mid-Atlantic plate boundary between Iceland and the Azores. Tectonophysics 55, 127-153.

Einarsson, P.A., 1991. Earthquakes and present-day tectonism in Iceland. Tectonophysics 189, 261-279.

Engdahl, E., van der Hilst, R., Buland, R., 1998. Global teleseismic earthquake relocation with improved travel times and procedures for depth determination. Bull. Seismol. Soc. Am. 88, 722-743.

Eshelby, J.D., 1957. The Determination of the Elastic Field of an Ellipsoidal Inclusion, and Related Problems. Proc. R. Soc. Lond. A 241, 376-396.

Francis, T.J.G., 1973. The seismicity of the Reykjanes Ridge. Earth Planet. Sci. Lett. 18, 119-123. 
Gee, J.S., Cande, S.C., Hildebrand, J.A., Donnelly, K., Parker, R.L., 2000. Geomagnetic intensity variations over the past 780 kyr obtained from near-seafloor magnetic anomalies. Nature 408, 827-832.

Goetze, C., Evans, B., 1979. Stress and temperature in the bending lithosphere as constrained by experimental rock mechanics. Geophysical Journal International 59, 463-478.

Hager, B.H., Clayton, R.W., Richards, M.A., Comer, R.P., Dziewonski, A.M., 1985. Global coupling of Earth surface topography with hotspots, geoid and mantle heterogeneities. Nature 313, 541-545.

Hager, B.H., Richards, M.A., 1989. Long-Wavelength Variations in Earth's Geoid: Physical Models and Dynamical Implications. Philos. Trans. R. Soc. Lond. A 328, 309-327.

Hanks, T., 1977. Earthquake Stress Drops, Ambient Tectonic Stresses and Stresses That Drive Plate Motions. Pure Appl. Geophys. 115, 441-458.

Hanks, T., Boore, D., 1984. Moment-magnitude relations in theory and practice. J. Geophys. Res. 89, 6229-6235.

Hanks, T., Kanamori, H., 1979. A moment magnitude scale. J. Geophys. Res. 84, 2348-2350.

Harding, A.J., Kent, G.M., Orcutt, J., 1993. A Multichannel Seismic Investigation of Upper Crustal Structure at $9^{\circ} \mathrm{N}$ on the East Pacific Rise: Implications for Crustal Accretion. J. Geophys. Res. 98, 13,925-13,944.

Hartley, R.A., Roberts, G.G., White, N.J., Richardson, C., 2011. Transient convective uplift of an ancient buried landscape. Nature Geosci. 4, 562-565.

Henstock, T., Woods, A., White, R.S., 1993. The accretion of oceanic crust by episodic sill intrusion. J. Geophys. Res. 98, 4143-4161.

Hey, R., Martinez, F., Höskuldsson, A., Benediktsdóttir, A., 2010. Propagating rift model for the V-shaped ridges south of Iceland. Geochem. Geophys. Geosyst 11, doi:10.1029/2009GC002865.

Huang, P., Solomon, S., 1988. Centroid Depths of Mid-Ocean Ridge Earthquakes: Dependence on Spreading Rate. J. Geophys. Res. 93, 13,445-13,477.

Ito, G., 2001. Reykjanes 'V'-shaped ridges originating from a pulsing and dehydrating mantle plume. Nature 411, 681-684.

Ito, G., Behn, M.D., 2008. Magmatic and tectonic extension at mid-ocean ridges: 2. Origin of axial morphology. Geochem. Geophys. Geosyst 9, doi:10.1029/2008GC001970.

Jones, S.M., Maclennan, J., Murton, B.J., Godfrey Fitton, J., White, N.J., 2010. New joint geochemical-geophysical record of time-dependent mantle convection south of Iceland. Abstract U44A-07 presented at 2010 Fall Meeting, AGU, San Francisco, California, 13-17 Dec .

Jones, S.M., White, N.J., Lovell, B., 2001. Cenozoic and Cretaceous transient uplift in the Porcupine Basin and its relationship to a mantle plume. Geol. Soc. Spec. Pub. 188, 345-360.

Jones, S.M., White, N.J., Maclennan, J., 2002. V-shaped ridges around Iceland: Implications for spatial and temporal patterns of mantle convection. Geochem. Geophys. Geosyst 3, doi:10.1029/2002GC000361.

Kanamori, H., 1983. Magnitude scale and quantification of earthquakes. Tectonophysics 93, 185-199.

Keeton, J., Searle, R.C., Peirce, C., Parsons, B., 1997. Bathymetry of the Reykjanes Ridge. Mar. Geophys. Res. 19, $55-64$.

Kent, D.V., Gee, J., 1996. Magnetic alteration of zero-age oceanic basalt. Geology 24, 703-706.

Kirby, S., 1983. Rheology of the lithosphere. Reviews of Geophysics 21, 1458-1487. 
Klitgord, K., 1976. Sea-floor spreading: The central anomaly magnetization high. Earth Planet. Sci. Lett. 29, 201-209.

Lee, S.M., Searle, R.C., 2000. Crustal magnetization of the Reykjanes Ridge and implications for its along-axis variability and the formation of axial volcanic ridges. J. Geophys. Res. 105, 5907-5930.

Levi, S., Audunsson, H., Duncan, R.A., Kristjansson, L., Gillot, P.Y., Jakobsson, S.P., 1990. Late Pleistocene geomagnetic excursion in Icelandic lavas: confirmation of the Laschamp excursion. Earth Planet. Sci. Lett. 96, $443-457$.

Maclennan, J., Hulme, T., Singh, S., 2004. Thermal models of oceanic crustal accretion: Linking geophysical, geological and petrological observations.

Magde, L.S., Smith, D., 1995. Seamount volcanism at the Reykjanes Ridge: Relationship to the Iceland hot spot. J. Geophys. Res. 100, 8449-8468.

Marshall, M., Cox, A., 1972. Magnetic Changes in Pillow Basalt Due to Sea Floor Weathering. J. Geophys. Res. 77, $6459-6469$

Morton, J.L., Sleep, N.H., 1985. A Mid-Ocean Ridge Thermal Model: Constraints on the Volume of Axial Hydrothermal Heat Flux. J. Geophys. Res. 90, 11,345-11353.

Murton, B.J., Taylor, R.N., Thirwall, M.F., 2002. Plume-Ridge Interaction: a Geochemical Perspective from the Reykjanes Ridge. J. Petrol. 43, 1987-2012.

Peirce, C., Sinha, M.C., Topping, S., Gill, C., 2007. Morphology and genesis of slow-spreading ridges-seabed scattering and seismic imaging within the oceanic crust. Geophys. J. Int. 168, 59-89.

Poore, H.R., Samworth, R., White, N.J., Jones, S.M., McCave, I.N., 2006. Neogene overflow of Northern Component Water at the Greenland-Scotland Ridge. Geochem. Geophys. Geosyst 7, doi:10.1029/2005GC001085.

Poore, H.R., White, N.J., Jones, S.M., 2009. A Neogene chronology of Iceland plume activity from V-shaped ridges. Earth Planet. Sci. Lett. 283, 1-13.

Poore, H.R., White, N.J., Maclennan, J., 2011. Ocean circulation and mantle melting controlled by radial flow of hot pulses in the Iceland plume. Nature Geosci. 4, 558-561.

Ranalli, G., 1995. Rheology of the Earth. Chapman \& Hall.

Sandwell, D.T., Smith, W.H.F., 2009. Global marine gravity from retracked Geosat and ERS-1 altimetry: Ridge segmentation versus spreading rate. J. Geophys. Res. 114, doi:10.1029/2008JB006008.

Schubert, G., Olson, P., 1989. Solitary waves in mantle plumes. J. Geophys. Res. 94, 9523-9532.

Schubert, G., Turcotte, D.L., Olson, P., 2001. Mantle Convection in the Earth and Planets. Cambridge University Press.

Searle, R.C., Field, P., Owens, R., 1994. Segmentation and a nontransform ridge offset on the Reykjanes Ridge near 58 N. J. Geophys. Res. 99, 24159-24.

Shorttle, O., Maclennan, J., 2011. Compositional trends of Icelandic basalts: Implications for shortlength scale lithological heterogeneity in mantle plumes. Geochem. Geophys. Geosyst 12, doi:10.1029/2011GC003748.

Shorttle, O., Maclennan, J., Jones, S.M., 2010. Control of the symmetry of plume-ridge interaction by spreading ridge geometry. Geochem. Geophys. Geosyst 11, doi:10.1029/2009GC002986.

Sibson, R.H., 1974. Frictional constraints on thrust, wrench and normal faults. Nature $249,542-544$. 
Sleep, N.H., 1974. Segregation of Magma from a Mostly Crystalline Mush. Geol. Soc. Am. Bull. 85, 1225-1232.

Sleep, N.H., 1975. Formation of Oceanic Crust: Some Thermal Constraints. J. Geophys. Res. 80, 4037-4042.

Smallwood, J.R., White, R.S., 1998. Crustal accretion at the Reykjanes Reykjanes Ridge. J. Geophys. Res. 103, $5185-5201$.

Smith, D., Cann, J., 1992. The role of seamount volcanism in crustal construction at the Mid-Atlantic Ridge $\left(24-30^{\circ} \mathrm{N}\right)$. J. Geophys. Res. 97, 1645-1658.

Smith, D., Cann, J., Dougherty, M., Lin, J., Spencer, S., Macleod, C.J., Keeton, J., McAllister, E., Brooks, B., Pascoe, R., 1995. Mid-Atlantic Ridge volcanism from deep-towed side-scan sonar images, 25-29² N. J. Volcanol. Geoth. Res. 67, 233-262.

Toomey, D., Solomon, S., Purdy, G., Murray, M., 1985. Microearthquakes beneath the median valley of the MidAtlantic Ridge near $23^{\circ} \mathrm{N}$ : Hypocenters and focal mechanisms. J. Geophys. Res. 90, 5443-5458.

VanTongeren, J.A., Kelemen, P.B., Hanghøj, K., 2008. Cooling rates in the lower crust of the Oman ophiolite: Ca in olivine, revisited. Earth Planet. Sci. Lett. 267, 69 - 82.

Vera, E.E., Mutter, J.C., Buhl, P., Orcutt, J.A., Harding, A.J., Kappus, M.E., Detrick, R.S., Brocher, T.M., 1990. The Structure of 0- to 0.2-m.y.-Old Oceanic Crust at $9^{\circ} \mathrm{N}$ on the East Pacific Rise From Expanded Spread Profiles. J. Geophys. Res. 95, 15,529-15,556.

Vogt, P.R., 1971. Asthenospehere motion recorded by the ocean floor south of Iceland. Earth Planet. Sci. Lett. 13, $153-160$.

Weertman, J., 1978. Creep laws for the mantle of the Earth. Phil. Trans. R. Soc. Lond. A. 288, 9-26.

White, R.S., 1997. Rift-plume interaction in the North Atlantic. Philos. Trans. R. Soc. Lond. A 355, 319-339.

Wright, J.D., Miller, 1996. Greenland-Scotland Ridge control of North Atlantic Deep Water. Paleoceanography 11, $157-170$.

Zhou, W., Voo, R.V.D., Peacor, D.R., Zhang, Y., 2000. Variable Ti-content and grain size of titanomagnetite as a function of cooling rate in very young MORB. Earth Planet. Sci. Lett. 179, 9-20.

\section{Figures}



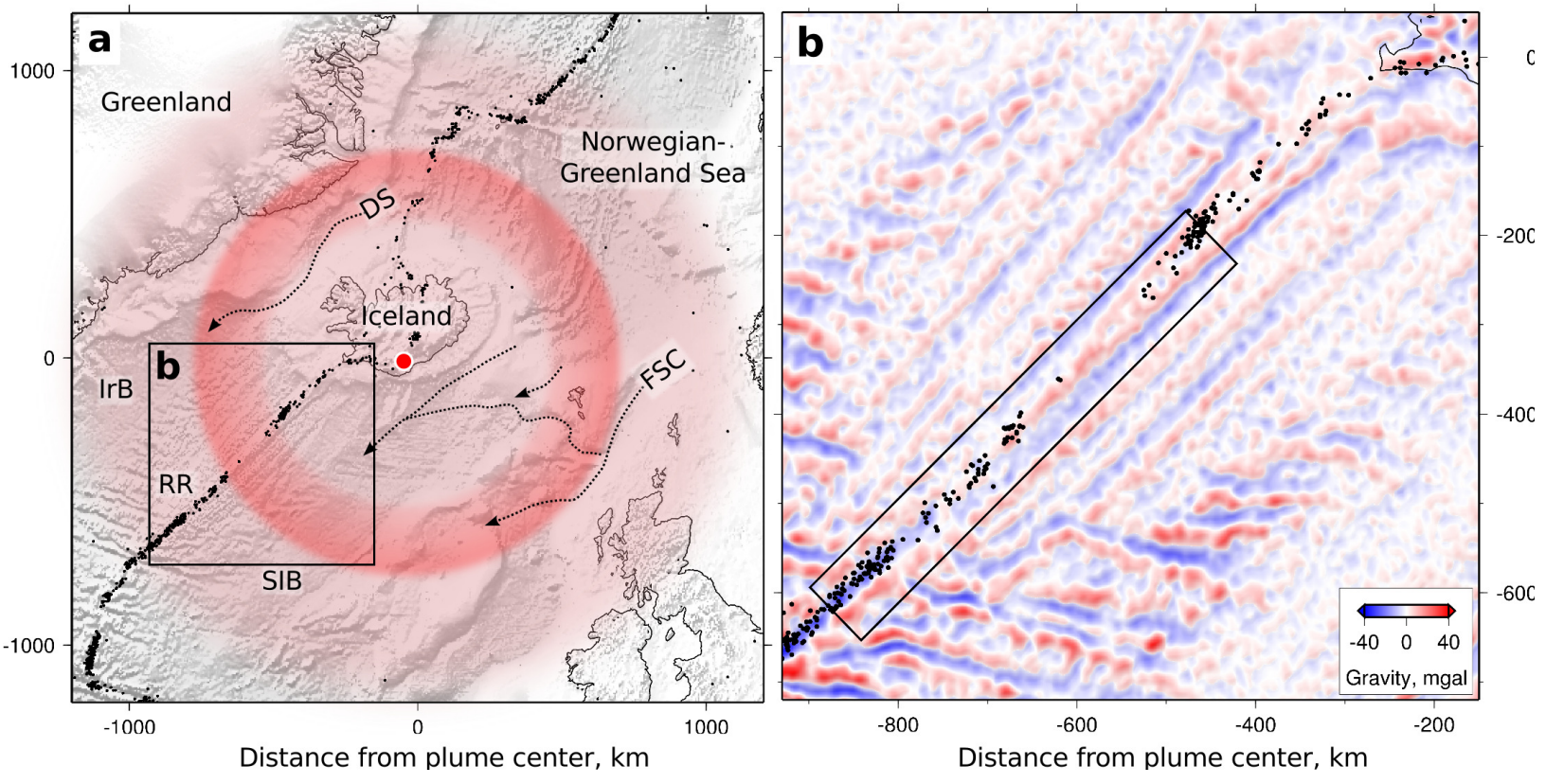

Figure 1: (a) Bathymetric map of North Atlantic Ocean showing idealized extent of Icelandic plume (projection centered on $\left.63.95^{\circ} \mathrm{N}, 17.4^{\circ} \mathrm{W}\right)$. Transparent red disk = present-day extent of plume; red ring = radial locus of transient thermal anomaly inferred at intersection of youngest V-shaped ridge with RR; small red circle = plume center (Shorttle et al., 2010); black circles = relocated earthquakes for 1960-2009 ( $M_{w}>4$; Engdahl et al., 1998). IrB $=$ Irminger Basin; RR = Reykjanes Ridge; SIB = South Iceland Basin; labeled dashed lines = deep-water pathways (FSC = Faroe-Shetland Channel overflow; DS = Denmark Straits overflow); black box = location of Figure 1b. (b) Short wavelength free-air gravity map of North Atlantic Ocean calculated from satellite-derived data (Sandwell and Smith, 2009) by removing wavelengths greater than $100 \mathrm{~km}$; black box = location of Figures 2a and 3. 

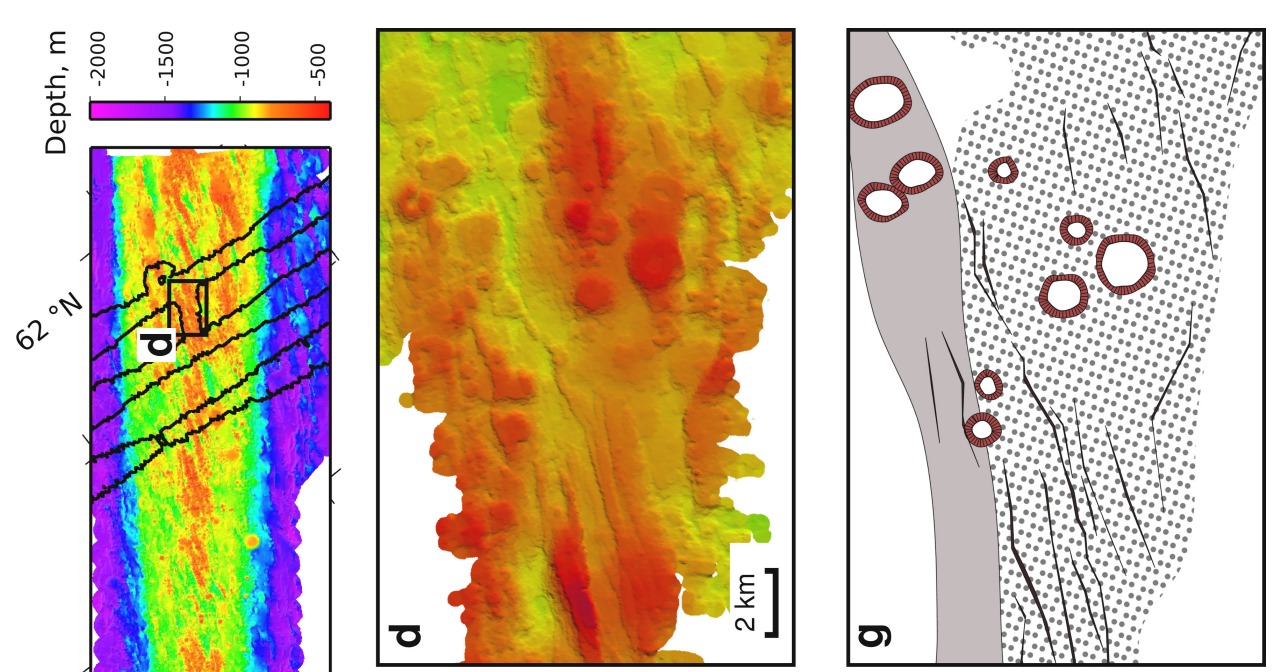

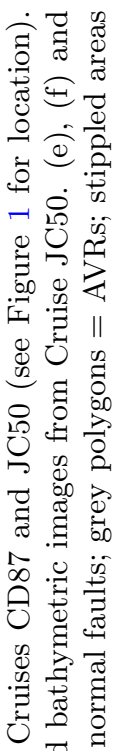

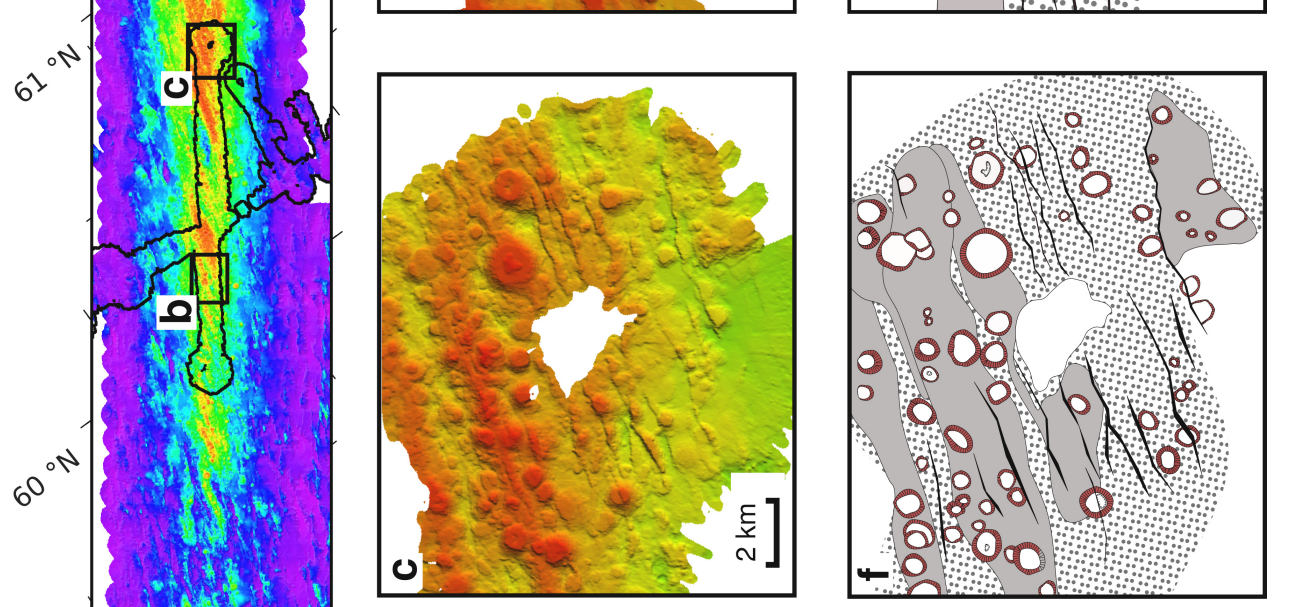

घ

要

苋苋

융

हี

营

嗼总

营㻤兽

a 0

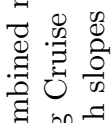

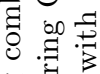

急要青

㻤

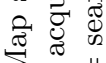

$\sum_{\pi} \|$

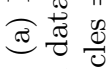

ن

항

嵒

串.

记

है

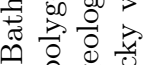

तi

焉苛

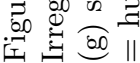



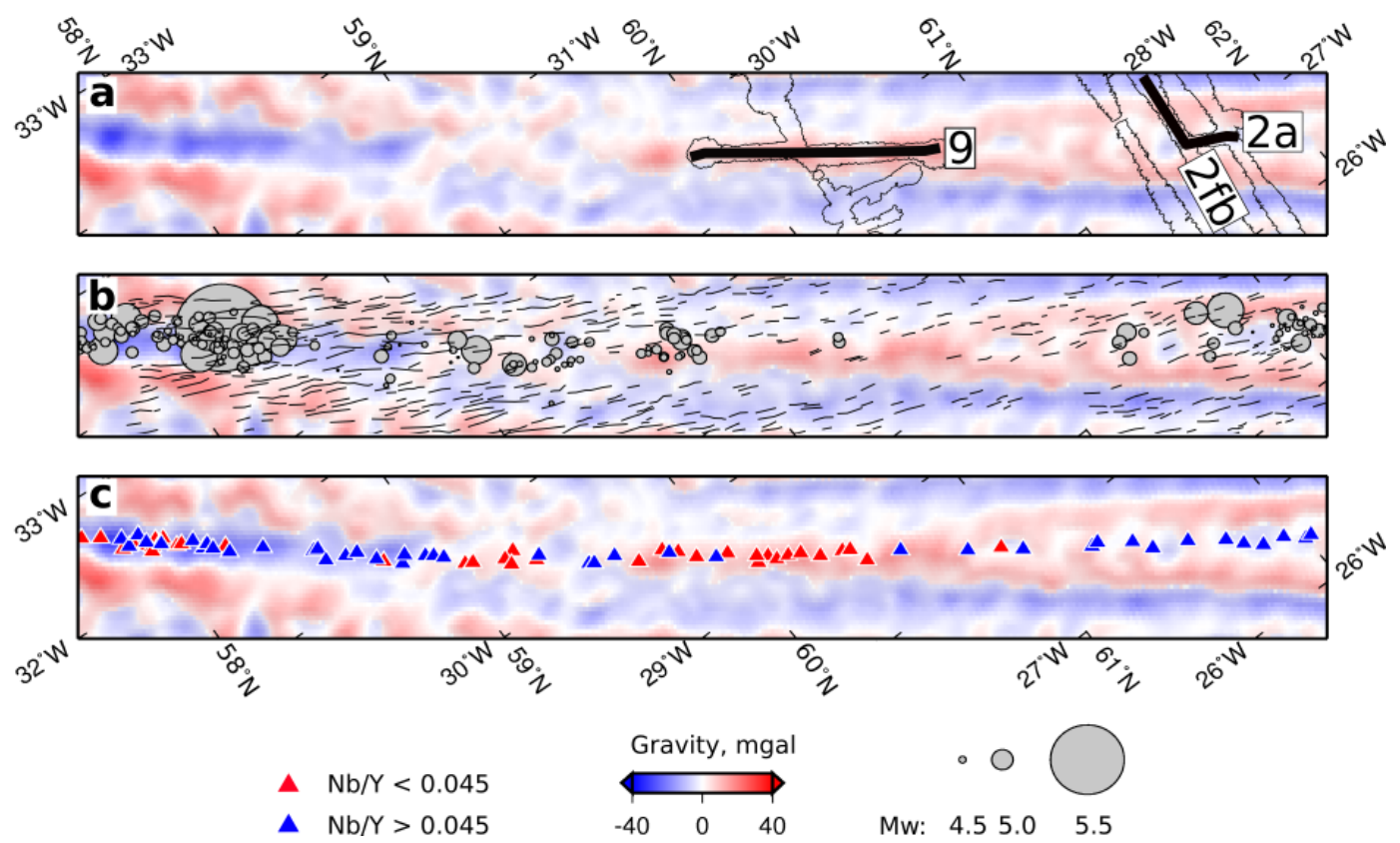

Figure 3: Geologic observations along and adjacent to RR overlain on short wavelength gravity anomalies (see Figure 1 for location). (a) Location of data acquired during Cruise JC50. Irregular polygons $=$ high resolution bathymetric data; labeled black lines $=2 \mathrm{D}$ seismic reflection profiles (emboldened lines shown in Figures 5 and 6). (b) Pattern of normal faulting. Gray circles = location of earthquakes with $M_{w}>4$, scaled relative to $M_{w}$ from 1960-2009 (Engdahl et al., 1998). Black lines = normal faults identified on bathymetry data of Keeton et al. (1997) and Cruise JC50. (c) Geochemistry of dredged basalts (Murton et al., 2002). Blue triangles $=\mathrm{Nb} / \mathrm{Y}>0.045$; red triangles $=$ $\mathrm{Nb} / \mathrm{Y}<0.045$.

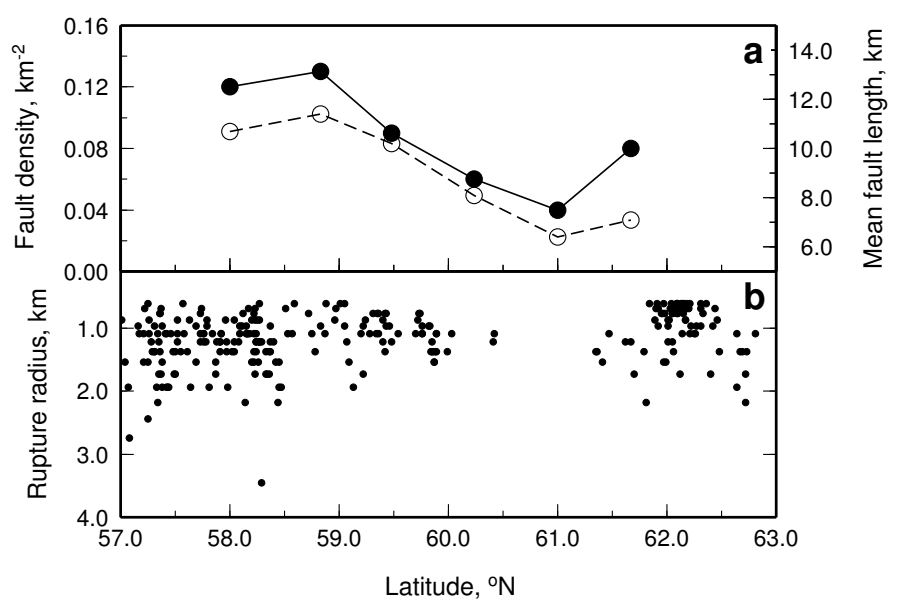

Figure 4: Fault characteristics as a function of distance along RR (a) Lengths of fault scarps, interpreted from multibeam bathymetric data of Cruise CD87 in $100 \mathrm{~km}$ bins. Solid circles $=$ fault density per $\mathrm{km}^{2}$; open circles $=$ mean fault length. (b) Calculated rupture radii of earthquakes with magnitude $>4$ from 1960-2009 (Engdahl et al., 1998). 


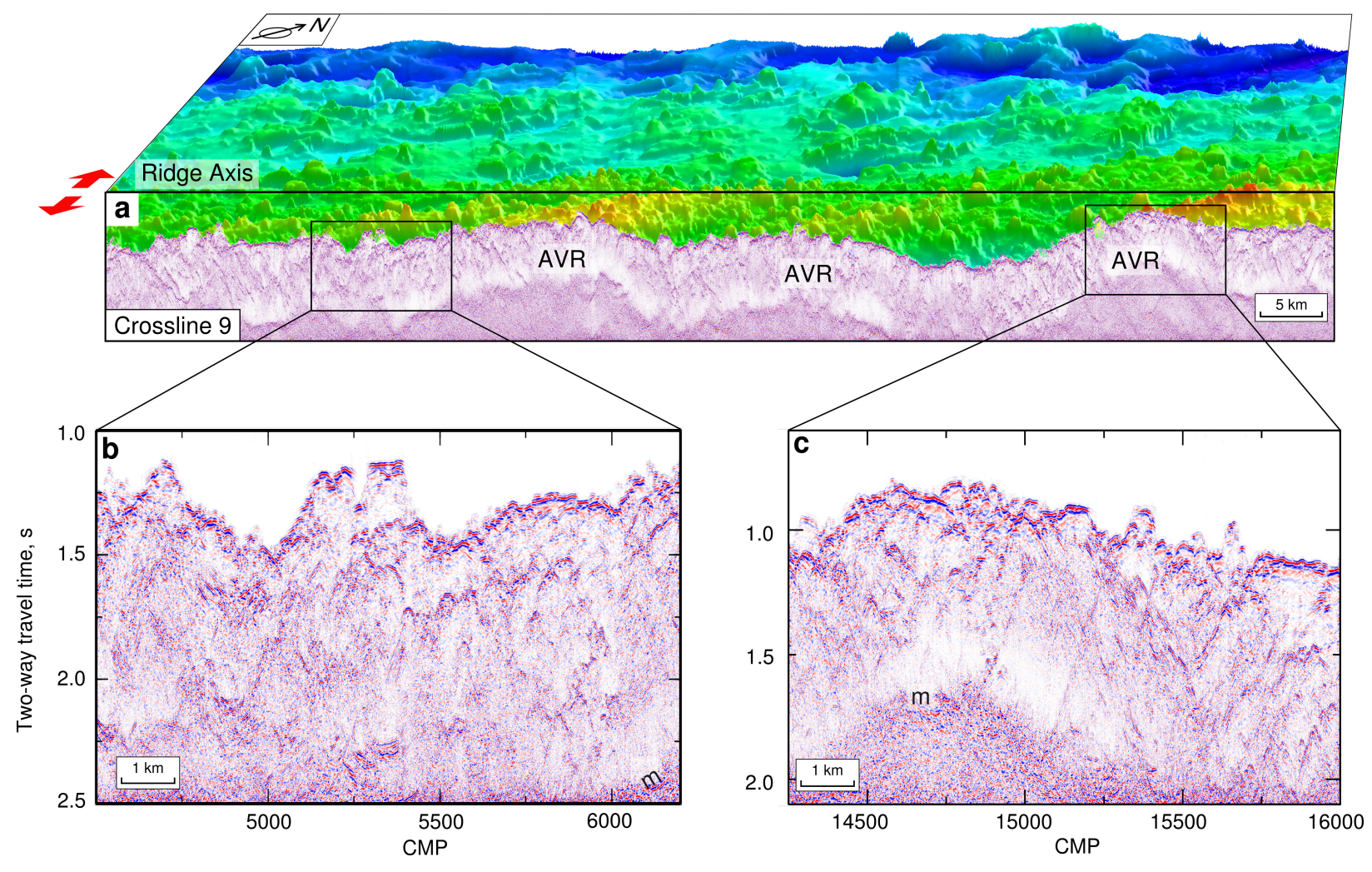

Figure 5: (a) Three-dimensional perspective view of RR showing multibeam bathymetric data from Cruise CD87 and seismic reflection data acquired on Cruise JC50 (see Figure 3 for location). Center of view is at $\sim 60.5^{\circ} \mathrm{N}$, looking to northwest. Red arrows $=$ plate spreading direction; AVR = loci of axial volcanic ridges. (b) and (c) Detailed sections of seismic reflection profile showing examples of seamounts, sideswipe and scattered energy. $\mathrm{m}=$ seabed multiple. 


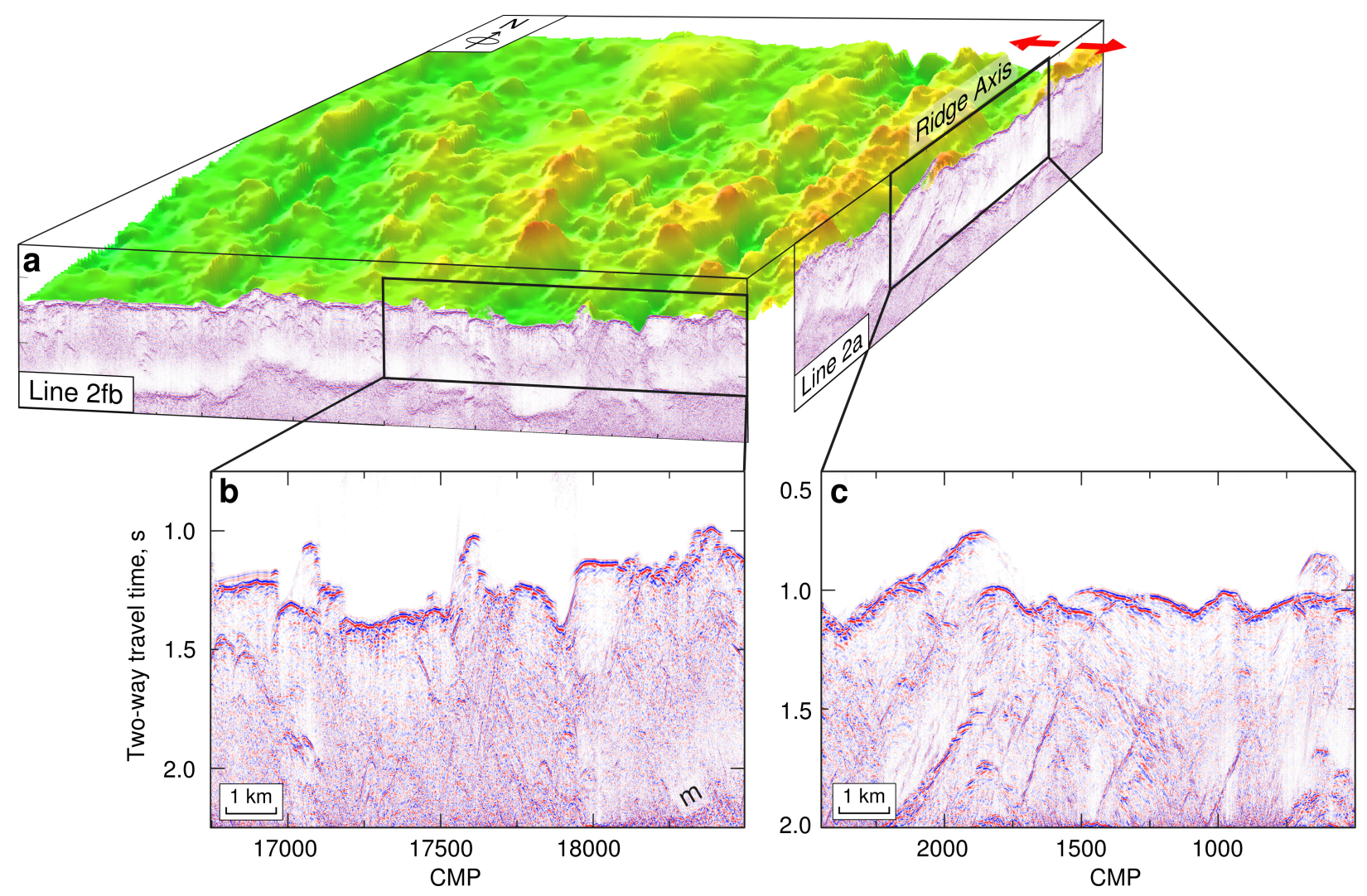

Figure 6: (a) Three-dimensional perspective view of RR showing multibeam bathymetric data from Cruise CD87 and seismic reflection lines $2 \mathrm{a}$ and $2 \mathrm{fb}$ acquired on Cruise JC50 (see Fig. 3 for location). Center of view is at $\sim 61.5^{\circ} \mathrm{N}$, looking to north. Red arrows = plate spreading direction. (b) and (c) Detailed sections of seismic reflection profiles. $\mathrm{m}=$ seabed multiple. 


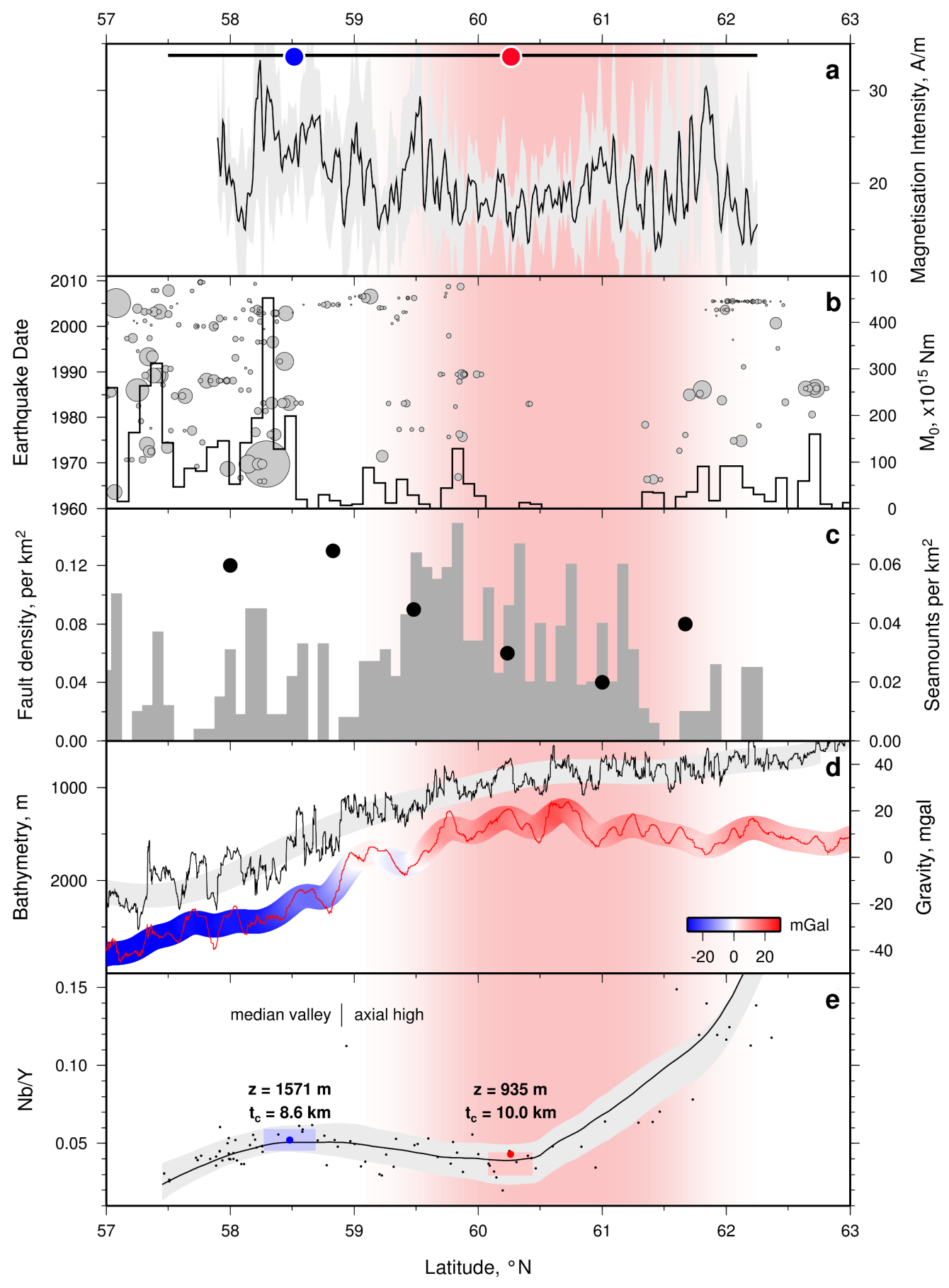

Figure 7: Summary of geophysical and geochemical observations along RR from $57^{\circ}$ to $63^{\circ} \mathrm{N}$. Vertical pink band delineates region where youngest V-shaped ridge intersects Reykjanes Ridge. (a) Black line with gray band = intensity of magnetization $\pm 1 \sigma$ along mid-oceanic ridge redrawn from Lee and Searle (2000); horizontal line along top $=$ extent of Figures 2 and 3. Red/blue circles = locations shown in Figure 9. (b) Seismicity between 1960-2009 (Engdahl et al., 1998). Scaled gray circles $=$ earthquakes with magnitude $>4$ within $\pm 35 \mathrm{~km}$ of ridge crest plotted as function of calendar year (see Fig. 3 for magnitude scaling); black line $=$ cumulative moment release, $\mathrm{M}_{0}$, using 5 arc minute $(\sim 9 \mathrm{~km})$ bins. (c) Solid circles = fault density interpreted from bathymetric data acquired on Cruise CD87 (Keeton et al., 1997); gray bars = seamount density binned per 5 arc minutes of latitude (Appelgate and Shor, 1994). (d) Black line = bathymetry, with polynomial fit; red line = satellite gravity anomaly (Sandwell and Smith, 2009), filtered to remove wavelengths longer than $100 \mathrm{~km}$; thick red/blue line = short wavelength satellite gravity anomaly with 1-degree width gaussian filter applied. (e) Geochemistry of dredged basalts. Black dots $=$ measured $\mathrm{Nb} / \mathrm{Y}$ (Murton et al., 2002); black line/grey band = best fitting line $\pm 1 \sigma$; red and blue circles $=$ calculated $\mathrm{Nb} / \mathrm{Y}$ for $T_{p}=1,354^{\circ} \mathrm{C}$ and $1,330^{\circ} \mathrm{C}$ respectively (Poore et al., 2011); bathymetry ( $\mathrm{z}$ ) and crustal thickness $\left(\mathrm{t}_{c}\right)$ at red and blue loci are shown. 


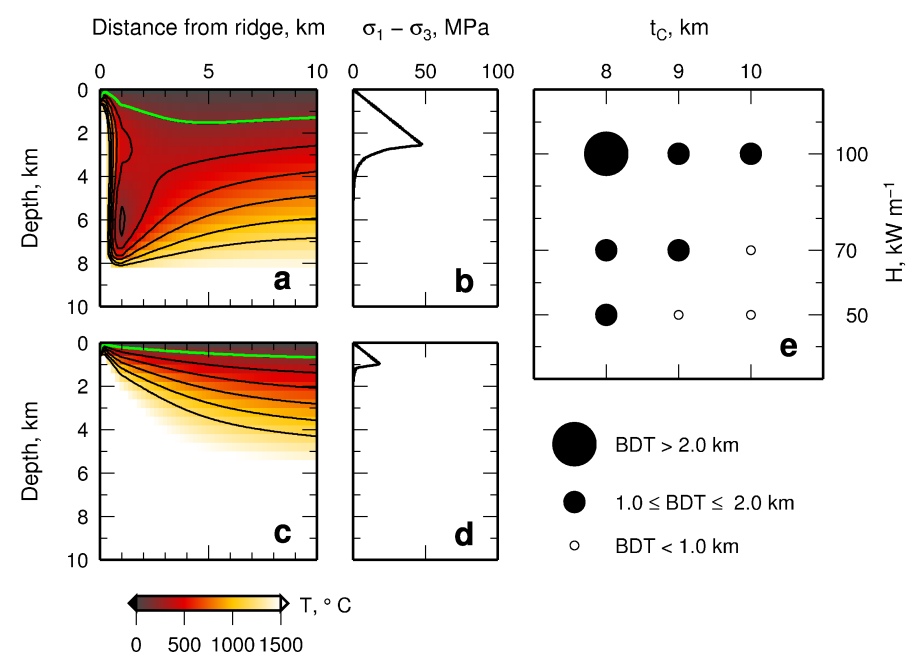

Figure 8: Thermal model of RR. (a) Temperature field for crustal thickness of $8 \mathrm{~km}, T_{l}$ of $1,330^{\circ} \mathrm{C}$ and total hydrothermal cooling of $100 \mathrm{kWm}^{-1}$. Green contour $=196^{\circ} \mathrm{C}$ isotherm. (b) Stress envelope calculated with temperature field shown in (a) at a distance $5 \mathrm{~km}$ from ridge crest. (c) Temperature field for crustal thickness of $10 \mathrm{~km}$, $T_{l}$ of $1,355^{\circ} \mathrm{C}$ and total hydrothermal cooling of $100 \mathrm{kWm}^{-1}$. Green contour $=196^{\circ} \mathrm{C}$ isotherm. (d) Stress envelope calculated with temperature field shown in (c) at a distance $5 \mathrm{~km}$ from ridge crest. (e) Depth of brittle-ductile transition $(\mathrm{BDT})$, calculated using nine models with varying crustal thickness $\left(\mathrm{t}_{c}\right)$ and total hydrothermal cooling (H). Open/closed circles scaled with depth of brittle-ductile transition depth. Results of all nine models are shown in Supplementary Fig. 1.

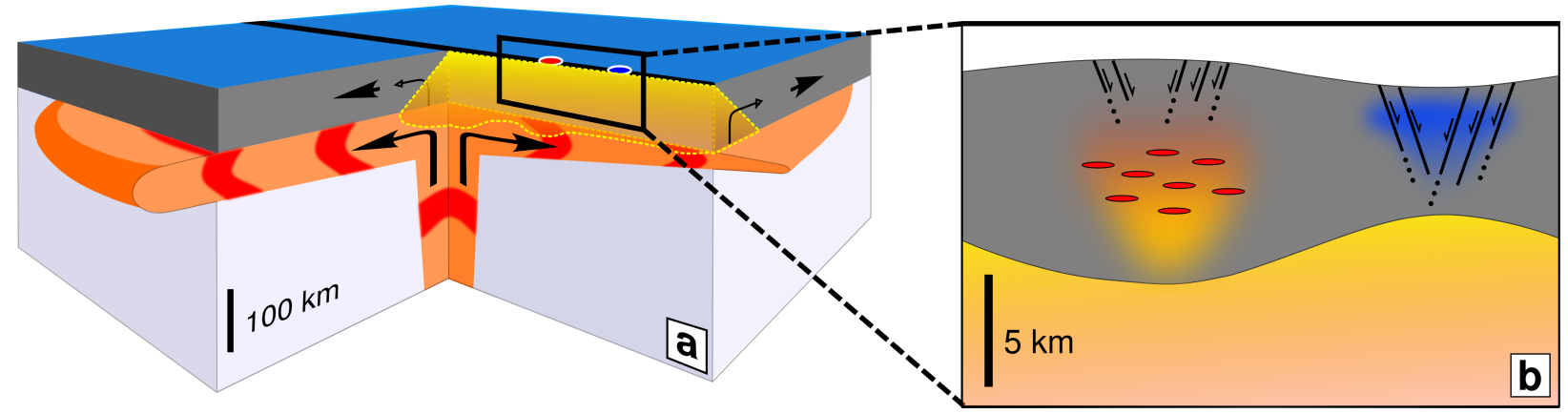

Figure 9: (a) Cut-away cartoon showing interaction between Icelandic plume and RR after Poore et al. (2011). Orange body with red patches = plume material flowing beneath lithosphere within which pulses of hotter than average material expand outward by Poiseuille flow at $\sim 40 \mathrm{~cm} / \mathrm{yr}$ (Poore et al., 2009); blue and gray block $=$ lithosphere; black line $=$ Reykjanes Ridge straddling the plume; red and blue loci as in Fig. 7; cut-away yellow prism = melting region below Reykjanes Ridge beneath which hot pulses travel; black arrows = plate motion, plume flow, and corner flow within the melting region. (b) Zoom-in cartoon showing crustal geometry above and beyond hot pulse flowing beneath the plate. Gray block = oceanic crust; yellow block = high viscosity melting prism which separates crust from asthenospheric channel; black lines with arrows = idealized pattern of normal faulting; red blobs, orange shading = idealized distribution of melt within hot, thickened crust; blue shading $=$ idealized extent of hydrothermal circulation within cold, thin crust. 


\begin{tabular}{ccccc}
\hline Symbol & Description & Value & Unit & Dimension \\
& & & & \\
\hline$u$ & Spreading half-rate & $3.2 \times 10^{-10}$ & $\mathrm{~m} \mathrm{~s}^{-1}$ & $\mathrm{~L} \mathrm{~T}^{-1}$ \\
$\rho$ & Density & $2.9 \times 10^{3}$ & $\mathrm{~kg} \mathrm{~m}^{-3}$ & $\mathrm{M} \mathrm{L}^{-3}$ \\
$c$ & Specific heat capacity & $1.085 \times 10^{3}$ & $\mathrm{~J} \mathrm{~kg}^{-1} \mathrm{~K}^{-1}$ & $\mathrm{~L}^{2} \mathrm{~T}^{-2} \Theta^{-1}$ \\
$L$ & Latent heat & $5.06 \times 10^{5}$ & $\mathrm{~J} \mathrm{~kg}^{-1}$ & $\mathrm{~L}^{2} \mathrm{~T}^{-2}$ \\
$k$ & Thermal conductivity & 2.5 & $\mathrm{~W} \mathrm{~m}^{-1} \mathrm{~K}^{-1}$ & $\mathrm{M} \mathrm{L} \mathrm{T}^{-3} \Theta^{-1}$ \\
$\kappa \frac{k}{\rho c}$ & Thermal diffusivity & $6.7 \times 10^{-7}$ & $\mathrm{~m}^{2} \mathrm{~s}^{-1}$ & $\mathrm{~L}^{2} \mathrm{~T}^{-1}$ \\
$z_{l}$ & Thickness of lithosphere & 100 & $\mathrm{~km}^{-1}$ & $\mathrm{~L}$ \\
$z_{s}$ & Depth of first melting & 80 & $\mathrm{~km}^{-1}$ & $\mathrm{~L}$ \\
$\theta$ & Dry adiabat & 0.3 & $\mathrm{~K} \mathrm{~km}^{-1}$ & $\Theta \mathrm{km}^{-1}$ \\
$\beta$ & Melting gradient & 3.0 & $\mathrm{~K} \mathrm{~km}^{-1}$ & $\Theta \mathrm{km}^{-1}$ \\
$\alpha$ & Liquid adiabat & 1.0 & $\mathrm{~K} \mathrm{~km}^{-1}$ & $\Theta \mathrm{km}^{-1}$ \\
$E$ & Molar activation energy & 260 & $\mathrm{~kJ} \mathrm{~mol}^{-1}$ & $\mathrm{M} \mathrm{L} \mathrm{L}^{2} \mathrm{~T}^{-2}$ \\
$R$ & Gas constant & 8.3145 & $\mathrm{~J} \mathrm{~K}^{-1} \mathrm{~mol}^{-1}$ & $\mathrm{M} \mathrm{L}^{2} \mathrm{~T}^{-2} \Theta^{-1}$ \\
$A$ & Material strength constant & $2.0 \times 10^{-4}$ & $\mathrm{MPa}^{-n} \mathrm{~s}^{-1}$ & $\mathrm{M} \mathrm{L} \mathrm{L}^{-1} \mathrm{~T}^{-3}$ \\
$\dot{\varepsilon}$ & Strain rate & $10^{-15}$ & $\mathrm{~s}^{-1}$ & $\mathrm{~T}^{-1}$ \\
$n$ & Power law exponent & 3.4 & - & - \\
\hline
\end{tabular}

Table 1: Constants used in thermal and mechanical calculations

\section{Appendix A. Thermal Model}

Boundary conditions are that the temperature at the top of the crust is $0{ }^{\circ} \mathrm{C}$ and the temperature at the base of the lithosphere, $T_{l}$, is constant (assuming a constant lithospheric thickness, $z_{l}$ ) and that far from the ridge the temperature approaches a conductive profile:

$$
\begin{array}{cc}
T=0 & z=0 \\
T=T_{l} & z=z_{l} \\
T \rightarrow \frac{T_{l} z}{z_{l}} & x \rightarrow \infty
\end{array}
$$


at the axis requires that horizontal heat flux is equal to amount of excess heat brought in by intrusions:

$$
-k \frac{\partial T}{\partial x}+u \rho c T=u \rho c\left(\frac{T_{l} z}{z_{l}}\right)+S(z)
$$

where $S(z)$ is a function describing heat brought in by intrusions (see Section 6 for details), $k$ is thermal conductivity, $\rho$ is density and $c$ is specific heat capacity.

First, we consider heat brought in by intrusion at the axis; latent heat is explicitly included in the adiabatic melting of ascending material and subsequent solidification of basaltic crust. Equation (2) is solved with the Fourier sine series expansion (Sleep, 1975):

$$
T=\left(\frac{1}{u \rho c}\right) \sum_{m=1}^{\infty} A_{m} B_{m} \sin \left(\frac{m \pi z}{z_{l}}\right) e^{a_{m} x}+\frac{T_{l} z}{z_{l}}
$$

where $m$ is the summation index, $A_{m}, B_{m}$ and $a_{m}$ are constants, details of which are given in Appendix B.

\section{Appendix B. Model for off-axis heat sinks}

We solve for the temperature field due to off-axis heat sinks in a similar manner to Morton and Sleep (1985), and combine with the results from Equation (A.2). The solution to Equation (2) for off-axis heat sinks is

$$
T=\sum_{m=1}^{\infty} A_{m} B_{m} \sin \left(\frac{m \pi z}{z_{l}}\right)\left[C_{m} e^{a_{m} x}+D_{m} e^{b_{m} x}\right]
$$

where are $C_{m}, D_{m}$ and $b_{m}$ are constants, details of which are given below. Equation (B.1) is solved separately for an array of heat sinks, and the results superimposed.

The constants in Equation (A.2) are evaluated as follows (Sleep, 1975)

$$
A_{m} \equiv 2\left(1+\sqrt{1+\frac{4 \kappa^{2} \pi^{2} m^{2}}{u^{2} z_{l}^{2}}}\right)^{-1}
$$




$$
\begin{aligned}
B_{m}=\frac{2 u \rho c}{m \pi}\left\{\cos \left(\frac{m \pi z_{s}}{z_{l}}\right)\left[\left(1-\frac{z_{s}}{z_{l}}\right) T_{l} \gamma-T_{s}+T_{l}\left(\frac{z_{s}}{z_{l}}\right)\right]\right. \\
+\frac{\sin }{m \pi}\left(\frac{m \pi z_{s}}{z_{l}}\right)\left(T_{l} \gamma+\beta z_{l}-T_{l}\right) \\
+\cos \left(\frac{m \pi t_{c}}{z_{l}}\right)\left(T_{s}-\left(z_{s}-t_{c}\right) \beta-\frac{L}{\rho c}-t_{c}\right) \\
\left.+\frac{\sin }{m \pi}\left(\frac{m \pi t_{c}}{z_{l}}\right)\left(\alpha z_{l}-\beta z_{l}\right)+\frac{L}{\rho c}\left(T_{c}-\alpha t_{c}\right)\right\} \\
a_{m} \equiv \frac{u}{2 \kappa}\left(1-\sqrt{1+\frac{4 \kappa^{2} \pi^{2} m^{2}}{u^{2} z_{l}^{2}}}\right) \\
\gamma=1-\left(\frac{\theta z_{l}}{T_{l}}\right)
\end{aligned}
$$

The total solution is calculated by superposition of the solution for each term in the sum. Constants in Equation (B.1) are evaluated as follows (Morton and Sleep, 1985)

$$
\begin{gathered}
C_{m}=\frac{-D_{m}\left(b_{m}-\frac{u}{\kappa}\right)}{\left(a_{m}-\frac{u}{\kappa}\right)} \\
D_{m}=\frac{Q_{i j} e^{\left(-b_{m} x_{j}\right)}}{\left(b_{m}-a_{m}\right) \kappa} \\
b_{m} \equiv \frac{u}{2 \kappa}\left(1+\sqrt{1+\frac{4 \kappa^{2} \pi^{2} m^{2}}{u^{2} z_{l}^{2}}}\right)
\end{gathered}
$$

